\title{
Interaction of phenanthrene and potassium uptake by wheat roots: a mechanistic model
}

Xinhua Zhan ${ }^{1,2^{*}}$, Xiao Liang ${ }^{1}$, Tinghui Jiang ${ }^{1}$ and Guohua Xu ${ }^{1}$

\begin{abstract}
Background: Polycyclic aromatic hydrocarbons (PAHs) are potentially carcinogenic, mutagenic and toxic to both human and non-human organisms. Dietary intake of PAHs is a dominant route of exposure for the general population where food crops are a major source of dietary PAHs. Over $20 \%$ of main food crops contain PAHs that exceed the control limits in China. However, the mechanisms on PAH accumulation in crops are not well understood.
\end{abstract}

Results: Here we report the physiological mechanism of potassium $\left(\mathrm{K}^{+}\right)$-stimulated uptake of phenanthrene (PHE, a model PAH) in wheat. PHE uptake is stimulated by the external $\mathrm{K}^{+}$. The addition of blockers (tetraethlyammonium and barium) for $\mathrm{K}^{+}$channels does not suppress the process, suggesting that $\mathrm{K}^{+}$channels are not involved. The introduction of PHE and $\mathrm{K}^{+}$elicits a much greater depolarization in root cell membrane potential than that of either PHE or $\mathrm{K}^{+} . \mathrm{K}^{+}$activates the plasma membrane proton $\left(\mathrm{H}^{+}\right)$-ATPase in a $\mathrm{K}^{+}$-dependent manner. The pattern is quite similar to that in PHE uptake in the presence of $\mathrm{K}^{+}$. The external medium $\mathrm{pH}$ treated with PHE and $\mathrm{K}^{+}$is higher than that with $\mathrm{K}^{+}$, and lower than that with $\mathrm{PHE}$, indicating that $\mathrm{H}^{+}$pump involves in the interaction between PHE and $\mathrm{K}^{+}$uptake.

Conclusions: Therefore, it is concluded that a $\mathrm{K}^{+}$influx $/ \mathrm{H}^{+}$efflux reaction is coupled with the transport of PHE into wheat root cells. Our results provide a novel insight into the PHE uptake by crop roots.

Keywords: Phenanthrene, Plasma membrane $\mathrm{H}^{+}$-ATPase, Polycyclic aromatic hydrocarbons, Potassium, Wheat root uptake

\section{Background}

Polycyclic aromatic hydrocarbons (PAHs) are ubiquitous environmental organic pollutants, deriving from natural or anthropogenic activities, especially from incomplete combustion or pyrolysis of organic material [1]. The annual $\mathrm{PAH}$ emission in China was estimated up to 114,000 tons in 2004, accounting for $29 \%$ of the global total [2]. Due to their carcinogenicity and toxicity to both human and non-human organisms, PAHs have been recognized as priority pollutants by the U.S. Environmental Protection Agency [3]. Dietary intake has been identified as the principal route of exposure to PAHs for the non-smoking population, with plant-based foodstuffs

\footnotetext{
* Correspondence: xhzhan@njau.edu.cn
${ }^{1}$ College of Resources and Environmental Sciences, Nanjing Agricultural

* Correspondence: xhzhan@njau.edu.cn
${ }^{1}$ College of Resources and Environmental Sciences, Nanjing Agricultural University, Nanjing, Jiangsu Province 210095, P.R. China ${ }^{2}$ State Key Laboratory of Soil and Sustainable Agriculture, Institute of Soil
Science, Chinese Academy of Sciences, Nanjing, Jiangsu Province 210008, ${ }^{2}$ State Key Laboratory of Soil and Sustainable Agriculture, Institute of Soil
Science, Chinese Academy of Sciences, Nanjing, Jiangsu Province 210008, P.R. China
}

(c) 2013 Zhan et al.; licensee BioMed Central Ltd. This is an open access article distributed under the terms of the Creative Commons Attribution License (http://creativecommons.org/licenses/by/2.0), which permits unrestricted use, distribution, and reproduction in any medium, provided the original work is properly cited.

constituting a major contributor to the total PAH intake [4-6]. Furthermore, it has been reported that over 20\% of main crops contain PAHs that exceed the relative control limit (5 $\mu \mathrm{g} \mathrm{kg}^{-1}$ benzo[a]pyrene) in China [7]. Therefore, it is important to find a way to reduce the uptake of PAHs by crops for food safety.

It has been well documented that plant roots can take up PAHs from soil or water contaminated with PAHs [8-13]. However, the mechanism of PAH uptake by plant roots is still not definitively understood. Our previous work has demonstrated that PAHs can enter the crop roots partly by passive transport and partly by active transport [14]. Passive transport of PAHs proceeds via aquaglyceroporins, and active transport is mediated by $\mathrm{H}^{+} / \mathrm{PAHs}$ symporters [15]. The cotransport of PAHs may be driven by a gradient of electrochemical potential for $\mathrm{H}^{+}$ across a membrane, which is generated and maintained by plasma membrane-bound ATPase. Evidence for symport of $\mathrm{H}^{+}$/PAHs includes: (a) alkalinization of the medium 
during PAH uptake; (b) transient depolarization of membrane in response to PAH supply; (c) inhibition of PAH uptake by metabolic inhibitors and ATPase inhibitors; and (d) stimulation of PAH uptake by low external $\mathrm{pH}$ [15].

Potassium $\left(\mathrm{K}^{+}\right)$is classified as an essential macronutrient for all plants. It is the most abundant ion in plant cells and is required for a wide array of functions, such as maintenance of electrical potential gradients across cell membranes, generation of turgor, and activation of numerous enzymes [16]. Hence, it is one of the major fertilizers frequently applied in agriculture.

It is well known that $\mathrm{K}^{+}$uptake is characterized by biphasic uptake kinetics, a low-affinity transport system (LATS) (mechanism 2, i.e., $\mathrm{K}^{+}$channel) and a high-affinity transport system (HATS) (mechanism 1, i.e., $\mathrm{K}^{+} / \mathrm{H}^{+}$symport) [17,18]. At low external concentrations (under $1 \mathrm{mM}$ ), the HATS operates and catalyzes an inward flux, against an electrochemical gradient, by use of a $\mathrm{K}^{+} / \mathrm{H}^{+}$ symport mechanism [19]. By contrast, the LATS dominates mostly via the activity of $\mathrm{K}^{+}$channels at high external concentrations (higher than $1 \mathrm{mM}$ ) [20]. $\mathrm{K}^{+}$uptake via HATS or LATS can trigger $\mathrm{H}^{+}$efflux [21,22], resulting in decrease in external medium $\mathrm{pH}[23,24]$. Whether $\mathrm{H}^{+}$efflux associated with $\mathrm{K}^{+}$uptake enhances the $\mathrm{H}^{+} / \mathrm{PAH}$ symport process is unknown.

In this paper, we hypothesize that a $\mathrm{K}^{+}$influx $/ \mathrm{H}^{+}$efflux reaction is coupled with the active uptake of PAHs into the root cells. The objectives are 1) to determine the dependence of PAH uptake upon $\mathrm{K}^{+}$influx, and 2) to reveal the mechanism on $\mathrm{K}^{+}$-stimulated PAH uptake. The investigation about the relationship of $\mathrm{PAH}$ and $\mathrm{K}^{+}$ uptake is beneficial for regulating PAH uptake by plant roots through decreased or increased $\mathrm{K}^{+}$fertilizer application in crop food safety and enhanced phytoremediation of PAH-contaminated soils or water. Here, we provide for the first time, to our knowledge, strong evidence of coupling between $\mathrm{H}^{+} / \mathrm{PAH}$ symport and $\mathrm{K}^{+}$ uptake.

\section{Results}

\section{Effect of $\mathrm{K}^{+}$on phenanthrene (PHE) uptake}

To examine the effect of $\mathrm{K}^{+}$on PHE uptake by wheat roots, different levels of $\mathrm{K}^{+}$were added to uptake solutions. Figure 1 depicts the $\mathrm{K}^{+}$-dependent PHE uptake. $\mathrm{K}^{+}$noticeably enhanced PHE uptake by roots of intact wheat seedlings in a nonlinear manner within $\mathrm{K}^{+}$concentrations of $0-12 \mathrm{mmol} \mathrm{L}^{-1}$ (Duncan's test, $P<0.05$ ). The enhancement was more obvious within $\mathrm{K}^{+}$range of $0-0.2 \mathrm{mmol} \mathrm{L}^{-1}$ with a rate (i.e. the increment of PHE uptake divided by the increment of $\mathrm{K}^{+}$concentration) of 184.05 as compared to that at higher $\mathrm{K}^{+}$range of $0.2-12 \mathrm{mmol} \mathrm{L}^{-1} \mathrm{~K}^{+}$with a rate of 4.34 .

\section{Effect of $\mathrm{K}^{+}$channel inhibitors on PHE uptake}

PHE uptake in the presence and absence of Tetraethlyammonium ion $\left(\mathrm{TEA}^{+}\right)$and Barium ion $\left(\mathrm{Ba}^{2+}\right)$ is shown in Figure 2. Although there existed slight fluctuation among the uptake data, the difference was not significant (Duncan's test, $P>0.05$ ).

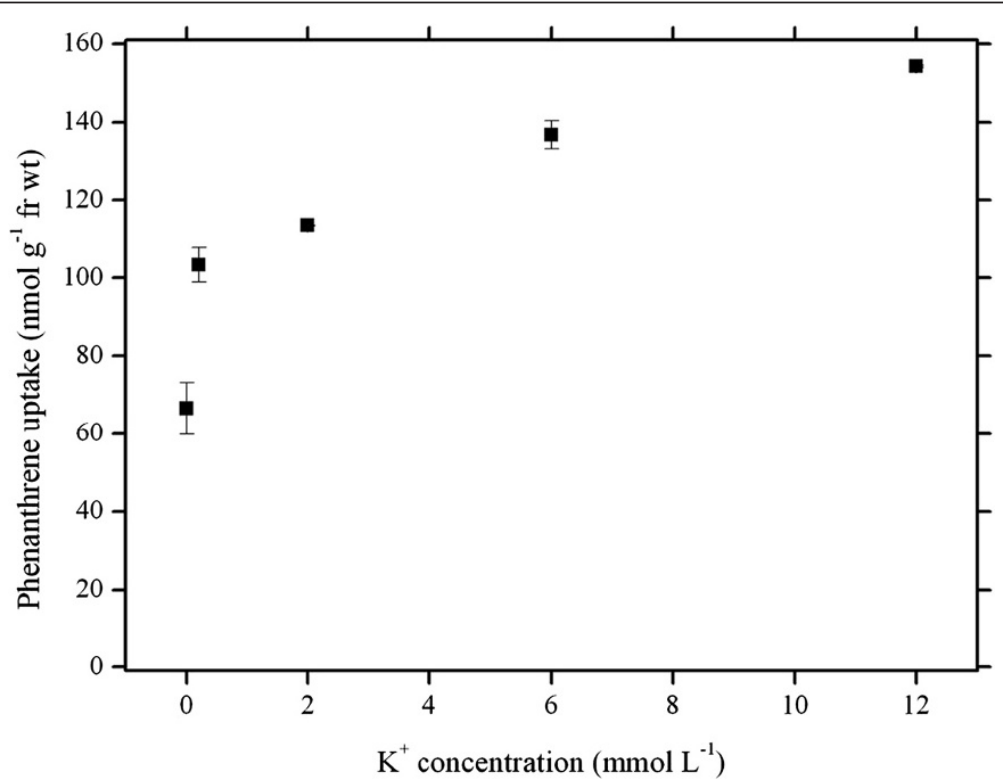

Figure $1 \mathrm{~K}^{+}$-stimulated phenanthrene uptake by wheat roots. The uptake of phenanthrene was performed at $25^{\circ} \mathrm{C}$ for $4 \mathrm{~h}$ in modified Hoagland nutrient solutions (i.e., potassium ions were replaced with sodium ions in nutrient solution, pH 5.5) with $5.62 \mu \mathrm{M}$ phenanthrene. Data points represent mean and SD values of triplicates. Error bars do not extend outside all data points. fr wt, Fresh weight. 


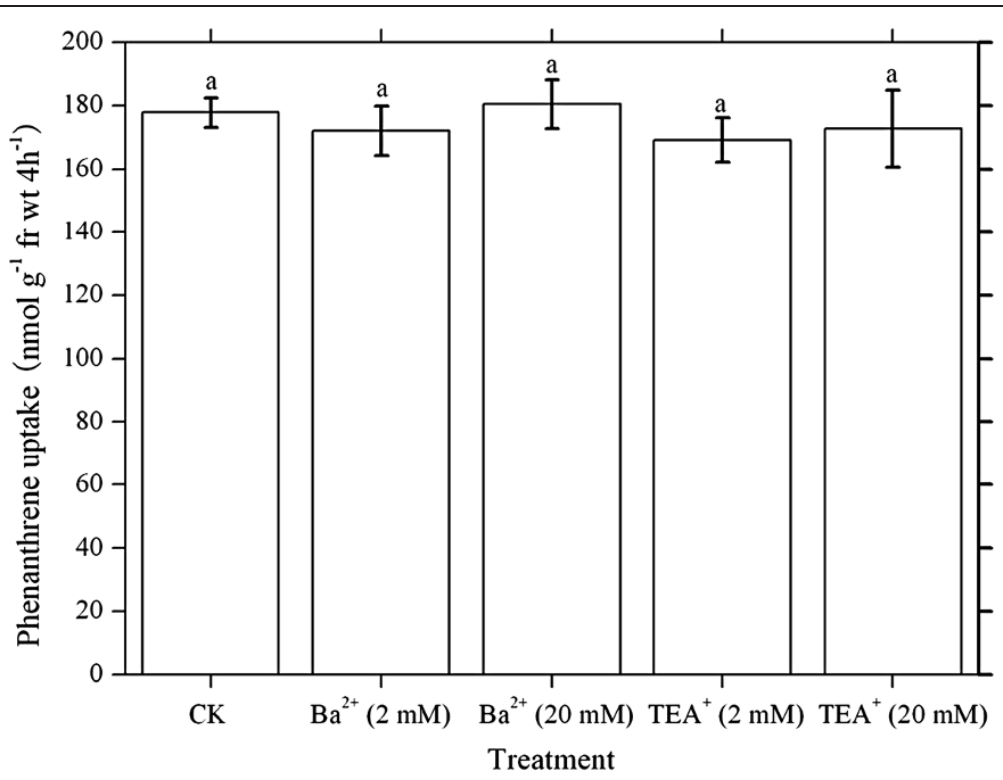

Figure 2 Uptake of phenanthrene in the presence or absence of blockers ( $\mathrm{TEA}^{+}$and $\mathrm{Ba}^{2+}$ ) for $\mathrm{K}^{+}$channels. Hydroponic solution was Hoagland nutrient solution ( $\mathrm{pH}$ 5.5) with $5.62 \mu \mathrm{M}$ phenanthrene. Each histogram bar represents the mean value of triplicates. Bars are the standard deviation of the mean. Data were subjected to one-way ANOVA and compared using the Duncan's test $(P<0.05)$. The same letters above the error bars indicate no significant differences. fr wt, Fresh weight. TEA ${ }^{+}$, Tetraethlyammonium.

\section{Effect of PHE and $\mathrm{K}^{+}$uptake on membrane potential}

The membrane of wheat root cells depolarized upon introduction of $\mathrm{K}^{+}$, PHE, or both $\mathrm{K}^{+}$and PHE (Figure 3). This depolarization was only transient. Depolarization recovered spontaneously while still in the presence of $\mathrm{K}^{+}$, PHE, or both $\mathrm{K}^{+}$and PHE. When either $\mathrm{K}^{+}$or PHE, or both $\mathrm{K}^{+}$and PHE were removed from the medium after repolarization completed, the membrane was transiently hyperpolarized and gradually depolarized to values approximately equal to the initial ones (Figure 3). Depolarization, repolarization, hyperpolarization and depolarization could be repeated three times with the

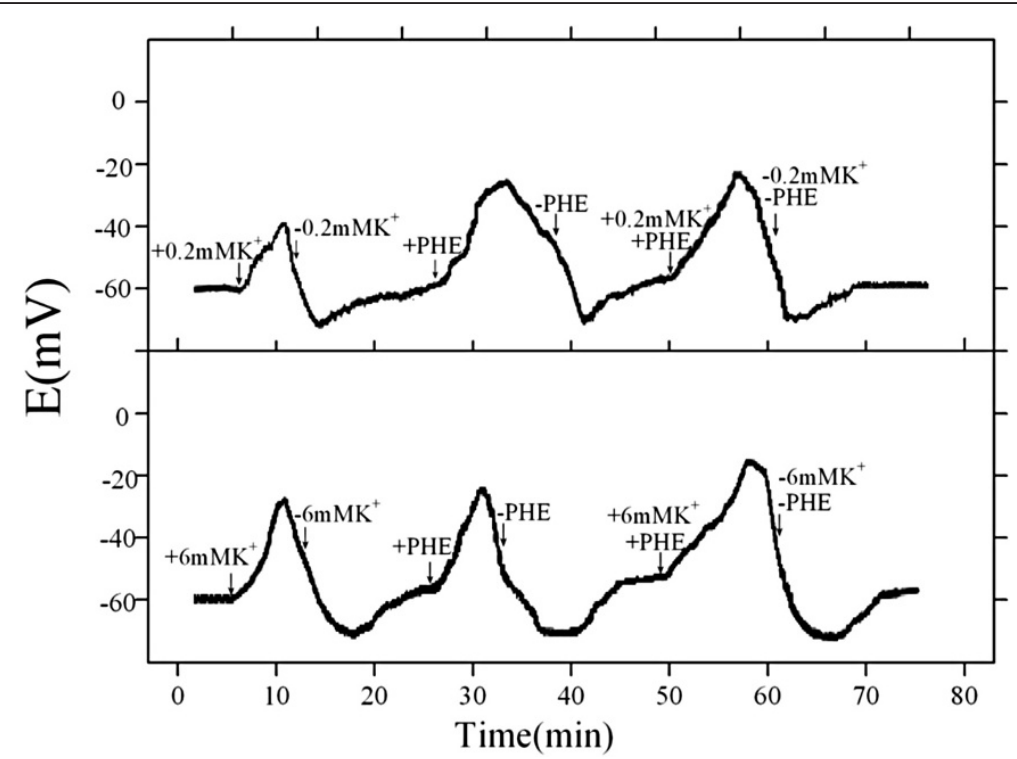

Figure 3 Phenanthrene-, potassium-, or phenanthrene plus potassium-induced membrane potential changes. Impalements were made in basal solution ( $5 \mathrm{mM}$ MES, $0.5 \mathrm{mM} \mathrm{CaCl} 2,0.05 \mathrm{mM} \mathrm{NaCl}$, pH 5.5) with or without $5.62 \mu \mathrm{M}$ phenanthrene, potassium, or $5.62 \mu \mathrm{M}$ phenanthrene plus potassium. Wheat roots grew for $15 \mathrm{~d}$. Arrows indicate times at which addition and removal of phenanthrene, $\mathrm{K}^{+}$, or phenanthrene and $\mathrm{K}^{+}$. MES, 2-(N-morpholino)ethanesulfonic acid. PHE, Phenanthrene. 
same root when it was exposed to $\mathrm{K}^{+}$-, PHE-, or $\mathrm{K}^{+}$and PHE-containing solutions and then to $\mathrm{K}^{+}$-, PHE-, or $\mathrm{K}^{+}$ and PHE-free solutions (data not shown). The depolarization displayed as a function of $\mathrm{K}^{+}$concentration. The higher $\mathrm{K}^{+}$concentration, the higher membrane potential of root cells depolarized (Figure 3). The depolarization elicited by PHE was stronger than by $\mathrm{K}^{+}$, and that induced by PHE and $\mathrm{K}^{+}$was greater than that by PHE or $\mathrm{K}^{+}$.

\section{Activity of plasma membrane $\mathrm{H}^{+}$-ATPase}

To characterize the changes in activity of plasma membrane $\mathrm{H}^{+}$-ATPase, the enzyme activity was determined at different $\mathrm{K}^{+}$concentrations in the presence of $5.62 \mu \mathrm{M}$ PHE. Figure 4 shows that the activities of plasma membrane $\mathrm{H}^{+}$-ATPase increased as $\mathrm{K}^{+}$concentration increased within the test range of 0-12 $\mathrm{mM}$. The activities increased dramatically at lower $\mathrm{K}^{+}$concentrations up to $0.2 \mathrm{mM}$; at higher $\mathrm{K}^{+}$concentrations, the activities increased slowly without reaching saturation.

\section{Effect of $\mathrm{K}^{+}$and PHE uptake on external medium $\mathrm{pH}$}

The addition of PHE caused a significant increase in solution $\mathrm{pH}$ (Duncan's test, $P<0.05$ ) (Table 1). The uptake of $\mathrm{K}^{+}$markedly reduced solution $\mathrm{pH}$ (Duncan's test, $P<0.05$ ), and the higher the $\mathrm{K}^{+}$concentration, the lower the $\mathrm{pH}$ was. The $\mathrm{pH}$ values treated with $\mathrm{K}^{+}$and PHE were higher than those treated with $\mathrm{K}^{+}$(Duncan's test, $P<0.05$ ), but lower than that treated with PHE (Duncan's test, $P<0.05$ ).
Table $1 \mathrm{pH}$ values of hydroponic solution initially and after $4 \mathrm{~h}$ of PHE uptake

\begin{tabular}{cccc}
\hline Treatment & $\mathbf{p H}_{\mathbf{1}}$ & $\mathbf{p H}_{\mathbf{2}}$ & $\mathbf{\Delta p H}$ \\
\hline Ck $\left(-\mathrm{K}^{+}-\mathrm{PHE}\right)$ & 5.50 & $5.47 \pm 0.06 \mathrm{~d}$ & $-0.03 \pm 0.06 \mathrm{~d}$ \\
$+5.62 \mu \mathrm{M} \mathrm{PHE}$ & 5.50 & $5.82 \pm 0.03 \mathrm{a}$ & $0.32 \pm 0.03 \mathrm{a}$ \\
$+0.2 \mathrm{mM} \mathrm{K}^{+}$ & 5.50 & $5.38 \pm 0.01 \mathrm{e}$ & $-0.12 \pm 0.01 \mathrm{e}$ \\
$+0.2 \mathrm{mM} \mathrm{K}^{+}+5.62 \mu \mathrm{M} \mathrm{PHE}$ & 5.50 & $5.72 \pm 0.03 \mathrm{~b}$ & $0.22 \pm 0.03 \mathrm{~b}$ \\
$+6 \mathrm{mM} \mathrm{K}^{+}$ & 5.50 & $5.32 \pm 0.02 \mathrm{f}$ & $-0.18 \pm 0.02 \mathrm{f}$ \\
$+6 \mathrm{mM} \mathrm{K}^{+}+5.62 \mu \mathrm{M} \mathrm{PHE}$ & 5.50 & $5.65 \pm 0.02 \mathrm{c}$ & $0.15 \pm 0.02 \mathrm{c}$ \\
\hline
\end{tabular}

Millipore water $(\mathrm{pH}$ 5.5) was employed for medium. Data were subjected to one-way ANOVA and compared using the Duncan's test $(P<0.05)$. Different letters in the same column indicate significant differences. PHE, phenanthrene. $\mathrm{pH}_{1}, \mathrm{pH}_{\text {initial. }} \cdot \mathrm{pH}_{2}, \mathrm{pH}_{\text {after } 4 \mathrm{~h}} . \Delta \mathrm{pH}=\mathrm{pH}_{\text {after } 4 \mathrm{~h}}-\mathrm{pH}_{\text {initial }}$.

\section{Discussion}

To date, little information is available on the interaction between $\mathrm{K}^{+}$and $\mathrm{PAH}$ uptake into plant roots, and the mechanisms underlying $\mathrm{K}^{+}$-stimulated $\mathrm{PAH}$ uptake remain unclear. Generally, the interaction between $\mathrm{K}^{+}$and PHE uptake may proceed directly by transport pathways or indirectly by altering environmental factors such as external medium $\mathrm{pH}$. If plants take up PHE in the same transport ways as $\mathrm{K}^{+}$(i.e. direct interaction), the presence of $\mathrm{K}^{+}$would inhibit PHE uptake. On the contrary, we have noticed that $\mathrm{K}^{+}$stimulates PHE transport into wheat roots (Figure 1), and the presence of $\mathrm{K}^{+}$channels blockers $\left(\mathrm{TEA}^{+}\right.$and $\mathrm{Ba}^{2+}$ ) doesn't repress PHE uptake due to no significant difference in PHE uptake by wheat roots between the treatments with and without $\mathrm{TEA}^{+}$or

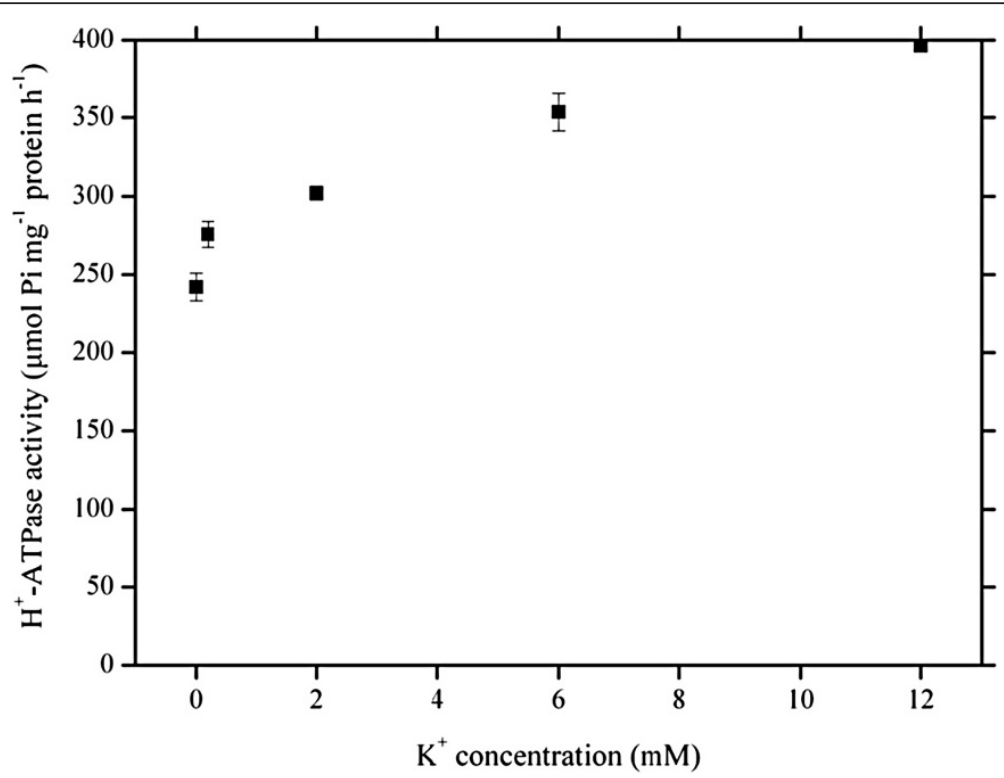

Figure $4 \mathrm{~K}^{+}$-dependent plasma membrane $\mathbf{H}^{+}$-ATPase activity. Phenanthrene concentration was $5.62 \mu \mathrm{M}$. $\mathrm{K}^{+}$varied from 0 to $12 \mathrm{mM}$. Data points represent mean and SD values of triplicates. Error bars do not extend outside all data points. Pi, inorganic $P$. 
$\mathrm{Ba}^{2+}$ (Figure 2). This means that PHE influx into wheat roots doesn't proceed via $\mathrm{K}^{+}$transport ways.

It has been well addressed that $\mathrm{K}^{+}$transport into plant roots triggers depolarization in membrane potential $[17,25]$. And, we have previously reported that a depolarization of membrane potential occurs upon addition of PHE into basal solution, and PHE is taken up by a $\mathrm{PHE} / \mathrm{H}^{+}$symport system [15]. The similar phenomena are also found in our electrophysiological measurements (Figure 3). Therefore, the combined treatment of PHE and $\mathrm{K}^{+}$leads to a greater depolarization of membrane potential, especially at higher $\mathrm{K}^{+}$level. Since the active transport for $\mathrm{PHE}$ proceeds via a $\mathrm{PHE} / \mathrm{H}^{+}$symport system, PHE uptake causes $\mathrm{H}^{+}$entrance into root cells, further triggering a depolarization in root cell membrane potential [15]. Thus, more positive charges pass into root cells in the treatment with both PHE and $\mathrm{K}^{+}$than with $\mathrm{PHE}$ or $\mathrm{K}^{+}$only, and then a much greater depolarization of membrane potential occurs in the treatment with PHE and $\mathrm{K}^{+}$. The subsequent repolarization in the presence of PHE, $\mathrm{K}^{+}$or both PHE and $\mathrm{K}^{+}$can be explained by increased activity of $\mathrm{H}^{+}$efflux pump stimulated by the increased cytosolic $\mathrm{H}^{+}$concentration [26]. The hyperpolarization upon withdrawal of PHE, $\mathrm{K}^{+}$or both $\mathrm{PHE}$ and $\mathrm{K}^{+}$ may have been due to the cessation of the solute $/ \mathrm{H}^{+}$symport carrier or the closure of $\mathrm{K}^{+}$channels while the $\mathrm{H}^{+}$-efflux pump still operates at an increased rate [26].

The plant plasma membrane $\mathrm{H}^{+}$-ATPase is very abundant in cells that are active in nutrient acquisition, and plays crucial roles in a number of essential physiological processes [27] such as energization of nutrient uptake, phloem loading, opening of stomata, generation of the electrochemical gradient of $\mathrm{H}^{+}$that provides the driving force for uptake of solutes through channel proteins and $\mathrm{H}^{+}$-coupled carriers [28], as well as the regulation of extra- and intracellular $\mathrm{pH}$. Because plasma membrane $\mathrm{H}^{+}$-ATPase can be stimulated by $\mathrm{K}^{+}$[29], its activity increases with an increase in $\mathrm{K}^{+}$concentrations as shown in our results (Figure 4). Moreover, the pattern of changes in plasma membrane $\mathrm{H}^{+}$-ATPase activity in response to increasing $\mathrm{K}^{+}$concentrations is considerably similar to that in PHE uptake (Figure 1). Therefore it is likely that $\mathrm{K}^{+}$-stimulated PHE uptake is indirectly coupled with an electrochemical $\mathrm{H}^{+}$gradient established due to the activation of plasma membrane $\mathrm{H}^{+}$-ATPase by $\mathrm{K}^{+}$ions, i.e., a $\mathrm{K}^{+}$influx $/ \mathrm{H}^{+}$efflux reaction is coupled with the active uptake of PAHs into the root cells.

Increase in $\mathrm{K}^{+}$ions in the hydroponic solution induces a further depolarization of root cell membrane (Figure 3), and thus promotes the release of $\mathrm{H}^{+}$into the external medium, causing a reduction in external medium $\mathrm{pH}$ (Table 1). The results are in good line with those observed by Sacchi et al. [30] and Du et al. [24]. At higher $\mathrm{K}^{+}$concentrations, the channel-mediated influx predominates, causing a greater release of $\mathrm{H}^{+}$in the external medium [30]. Therefore, the external medium $\mathrm{pH}$ at $6 \mathrm{mM} \mathrm{K}^{+}$is lower than that at $0.2 \mathrm{mM} \mathrm{K} \mathrm{K}^{+}$(Table 1). Due to an increase in external medium $\mathrm{pH}$ for the operation of the $\mathrm{H}^{+} / \mathrm{PHE}$ symport system and a decrease in external medium $\mathrm{pH}$ for $\mathrm{K}^{+}$uptake, the external medium $\mathrm{pH}$ in the presence of $\mathrm{PHE}$ and $\mathrm{K}^{+}$is much higher than that in the presence of $\mathrm{K}^{+}$only (Table 1 ). The changes in external medium $\mathrm{pH}$ during root uptake of PHE with and without $\mathrm{K}^{+}$further support our hypothesis that $\mathrm{K}^{+}$-stimulated PHE uptake is coupled with $\mathrm{H}^{+}$pump activated by $\mathrm{K}^{+}$. Based on our results and the mechanism for $\mathrm{K}^{+}$transport into plant root cells proposed by Britto and Kronzucker [22], a model for interaction between $\mathrm{K}^{+}$and PHE uptake is proposed (Figure 5). In this model, the $\mathrm{H}^{+} / \mathrm{PHE}$ symport system is associated with a $\mathrm{K}^{+}$influx $/ \mathrm{H}^{+}$efflux reaction.

\section{Conclusions}

We have observed the interaction of PHE and $\mathrm{K}^{+}$uptake, and proposed a mechanistic model for the interaction. To our knowledge, this is the first report on the topic. The data presented here show that the PHE uptake is dependent on the external medium $\mathrm{K}^{+}$concentrations. The inhibitors for $\mathrm{K}^{+}$channels have no effect on PHE uptake. The presence of PHE and $\mathrm{K}^{+}$triggers a greater depolarization of root cell membrane as compared to that of PHE or $\mathrm{K}^{+}$only, resulting in a higher external medium $\mathrm{pH}$. The activity of plasma membrane $\mathrm{H}^{+}$-ATPase is activated by $\mathrm{K}^{+}$. Therefore, the $\mathrm{K}^{+}$-enhanced uptake of PHE is a result of a coupling of $\mathrm{H}^{+}$-PHE symport into wheat roots and a $\mathrm{K}^{+}$influx $/ \mathrm{H}^{+}$efflux reaction. Our results provide a novel insight into the PAH uptake by crop roots.

\section{Methods}

\section{Chemicals}

PHE, a model compound of PAHs [31,32], was purchased from Fluka Chemical Corporation with purity $>97 \%$. It has molecular weight of $178.2 \mathrm{~g} \mathrm{~mol}^{-1}$, and water solubility of $7.3 \mu \mathrm{mol} \mathrm{L} \mathrm{L}^{-1}$ at $25^{\circ} \mathrm{C}$ [33]. All organic solvents used for extraction and analysis of PHE were of high performance liquid chromatography (HPLC) grade.

\section{Plant germination and cultivation}

Wheat (Triticum aestivum L.) seeds were surfacesterilized in $10 \% \mathrm{H}_{2} \mathrm{O}_{2}$ for $10 \mathrm{~min}$. They were then germinated on moistened filter paper for $4 \mathrm{~d}$ at $25^{\circ} \mathrm{C}$ in the dark after thorough rinsing with Millipore (Milli-Q, Billerica, MA, USA) water. The wheat seedlings were transplanted to black plastic pots containing $2500 \mathrm{~mL}$ half-strength aerated Hoagland nutrient solution for $5 \mathrm{~d}$ and then transferred to the full-strength Hoagland solution for $5 \mathrm{~d}$. The nutrient solution was prepared with Millipore water and the initial $\mathrm{pH}$ of the solution was adjusted to 5.5. Wheat seedlings were grown in a 

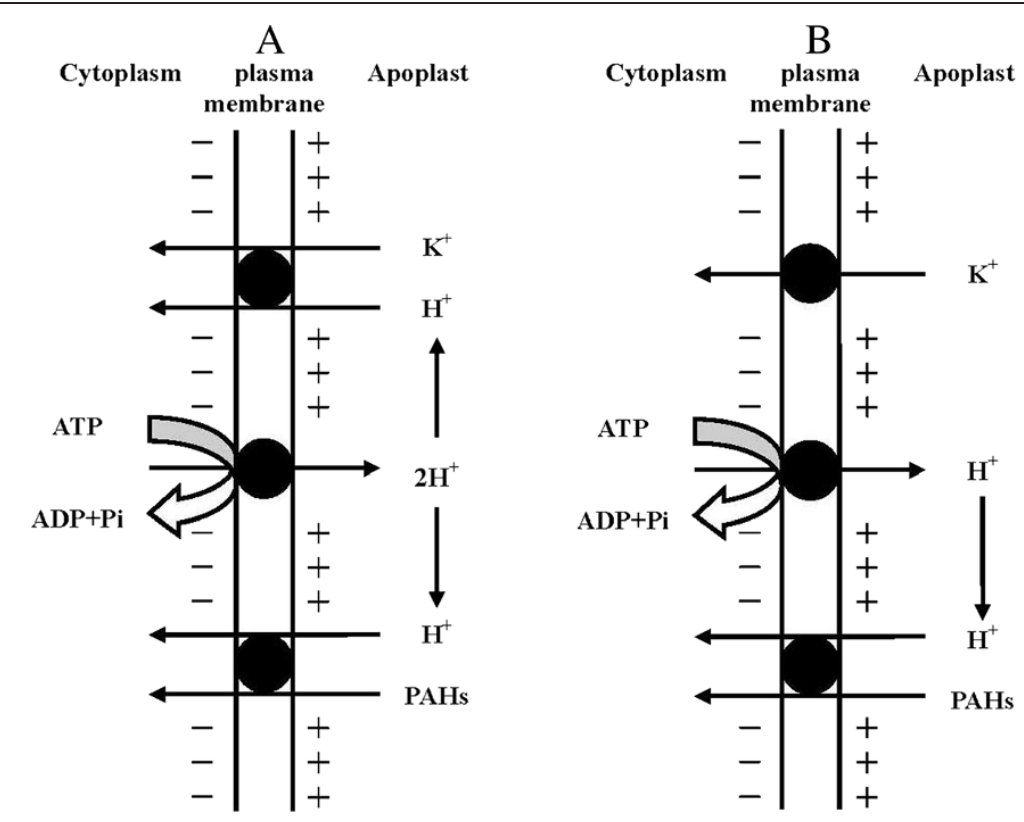

Figure 5 A conceptual model proposed for the coupling of phenanthrene transport into root cells and a potassium influx/proton efflux reaction. $\mathbf{A}$ is for the high-affinity potassium transport system (HATS), $\mathbf{B}$ is for the low-affinity potassium transport system (LATS). In HATS, the symport of $\mathrm{H}^{+} / \mathrm{K}^{+}$activates proton pump mediated by plasma membrane $\mathrm{H}^{+}$-ATPase, then forming a transmembrane electrochemical proton gradient. The electrochemical proton gradient drives the phenanthrene/proton symport system. In LATS, $\mathrm{K}^{+}$influx via channels stimulates proton pump, and establishes an electrochemical proton gradient acting as a driving force for $\mathrm{H}^{+} /$phenanthrene symport. Pi, inorganic P. PAHs, polycyclic aromatic hydrocarbons.

controlled-climate chamber with a light/dark regime of $16 / 8 \mathrm{~h}$ at $25 / 20^{\circ} \mathrm{C}$, a relative humidity of $60 \%$, and a light intensity of $400 \mu \mathrm{mol} \mathrm{m} \mathrm{m}^{-2} \mathrm{~s}^{-1}$. After 10 -d growth in Hoagland nutrient solution, the wheat seedlings were immersed in Millipore water for $24 \mathrm{~h}$ and then employed in the subsequent PHE uptake and electrophysiological study.

\section{$\mathrm{K}^{+}$-dependent uptake of PHE}

Twenty intact 15 -d-old wheat seedlings with uniform size were transferred to $600-\mathrm{mL}$ beakers containing $500 \mathrm{~mL}$ aerated, full-strength, modified Hoagland nutrient solution (i.e., potassium ions were replaced with sodium ions in nutrient solution, $\mathrm{pH}$ 5.5) with $5.62 \mu \mathrm{M}$ PHE and $0.05 \%$ methanol as a solvent. In order to improve the dissolution of PHE in nutrient solution, PHE stock solution prepared with methanol as a solvent was added. The methanol concentration was less than $0.1 \%$ and had no impact on root growth [34]. The uptake of PHE was detected at $25^{\circ} \mathrm{C}$ after $4 \mathrm{~h}$ of uptake in the modified Hoagland nutrient solution at $\mathrm{K}^{+}$concentrations of $0,0.2,2,6$, and $12 \mathrm{mM}$. There were triplicates per treatment.

\section{PHE uptake in the presence of $\mathrm{K}^{+}$channel blockers}

Although $\mathrm{TEA}^{+}$and $\mathrm{Ba}^{2+}$ can suppress the uptake of some cations like $\mathrm{Na}^{+}$and $\mathrm{NH}_{4}^{+}$[35-37], they are well- known inhibitors of $\mathrm{K}^{+}$channels, and block channel conductance by interacting with sites normally occupied by $\mathrm{K}^{+}$ions [38-40]. Therefore, $\mathrm{TEA}^{+}$and $\mathrm{Ba}^{2+}$ were utilized as blockers of $\mathrm{K}^{+}$channel in this study. Each was employed at concentrations of 2 and $20 \mathrm{mM}$ [41] in Hoagland nutrient solution ( $\mathrm{pH} 5.5$ ) with $5.62 \mu \mathrm{M}$ PHE and $0.05 \%$ methanol. The procedures were the same as those in $\mathrm{K}^{+}$-dependent uptake of PHE.

\section{Membrane potential measurements}

Wheat (15 d old) root tip was excised, and mounted in a Plexiglas chamber attached to the stage of an Olympus compound microscope, which was fixed to the surface of a vibration-damped table (Kinetic Systems Inc.). The Plexiglas chamber was perfused with basal solution (5 mM 2-(N-morpholino) ethanesulfonic acid (MES), $0.5 \mathrm{mM} \mathrm{CaCl}_{2}, 0.05 \mathrm{mM} \mathrm{NaCl}, 0.05 \%$ methanol, pH 5.5) at a flow rate of $10 \mathrm{~mL} \mathrm{~min}^{-1}$ for $2 \mathrm{~h}$ before the measurements. Impalement of micropipette into root epidermal cells was made in a region about 1 to $2 \mathrm{~cm}$ from the root apex, using a hydraulically driven Narashige micromanipulator mounted on the microscope stage [42,43]. Micropipettes with a tip diameter of $<0.5 \mu \mathrm{m}$ were pulled from filament-containing borosilicate glass capillaries (Clark, GC $150 \mathrm{~F}$ ) with a vertical puller (PE-21, Narishige Scientific Instrument Lab, Japan). The micropipettes were filled with $0.1 \mathrm{M} \mathrm{KCl}$, and the reference 
salt bridge with $0.1 \mathrm{M} \mathrm{KCl}$ in $2 \%$ agar. They were connected by $\mathrm{Ag} / \mathrm{AgCl}$ electrodes to a WPI amplifier, model FD223. The reference electrode was kept in the perfusion chamber in the vicinity to the root. Measured membrane potentials of root cells, which are the voltage differences between the impaling and reference electrodes, were amplified and recorded on a strip chart recorder. When the resting potential (measured in basal solution) was constant, basal solution was replaced by test solution. The measurements were conducted in the dark at room temperature (about $25^{\circ} \mathrm{C}$ ).

\section{Determination of plasma membrane $\mathrm{H}^{+}$-ATPase activity}

Plasma membrane vesicles were isolated according to Yan et al. [44]. Plasma membrane $\mathrm{H}^{+}$-ATPase activity was determined as described by Liang et al. [45] with some modifications. Isolated vesicles of plasma membrane $(50 \mu \mathrm{L})$ were added into $450 \mu \mathrm{L}$ of reaction medium, containing $30 \mathrm{mMN}$-2-hydroxyethyl piperazine$N^{\prime}$-2-ethanesulfonic acid (Hepes)-hydroxymethyl aminomethane (Tris) ( $\mathrm{pH}$ 6.5), $50 \mathrm{mM} \mathrm{NaNO}_{3}, 3 \mathrm{mM} \mathrm{MgSO}_{4}$, $0.1 \mathrm{mM}$ ammonium molybdate, $2 \mathrm{mM}$ ATP- $\mathrm{Na}_{2}$, $5.62 \mu \mathrm{M}$ PHE and $0.05 \%$ methanol, at $\mathrm{K}^{+}$concentrations of $0,0.2,2,6$, and $12 \mathrm{mM}$. After $20 \mathrm{~min}$ of incubation at $37^{\circ} \mathrm{C}$, reaction was terminated by adding $50 \mu \mathrm{L}$ of trichloroacetic acid. Inorganic phosphate $(\mathrm{Pi})$ released from ATP hydrolysis was determined by the colorimetric molybdenum blue method. Protein in membrane vesicles was analyzed colorimetrically at $595 \mathrm{~nm}$ based on the formation of protein-dye complex (the binding of Coomassie Brilliant blue G-250 to protein) using bovine serum albumin as the standard. Plasma membrane $\mathrm{H}^{+}$-ATPase activity is expressed as $\mu \mathrm{mol} \mathrm{Pi} \mathrm{mg} \mathrm{mg}^{-1}$ protein $\mathrm{h}^{-1}$.

\section{Change in incubation solution $\mathrm{pH}$}

External medium $\mathrm{pH}$ alteration depends mainly on $\mathrm{H}^{+}$efflux caused by the activity of plasma membrane $\mathrm{H}^{+}$-ATPase and on $\mathrm{H}^{+}$influx from cotransport activity. To facilitate the detection of $\mathrm{pH}$ changes in $\mathrm{K}^{+}$-, PHE-, or $\mathrm{K}^{+}$and PHE- incubation solutions, the contribution of other cations and anions was minimized. For this purpose, the experiments were performed in Millipore water. Wheat roots were immersed in six sorts of incubation solution with initial $\mathrm{pH}$ of 5.5: (1) Millipore water, (2) Millipore water with $5.62 \mu \mathrm{M}$ PHE, (3) Millipore water with $0.2 \mathrm{mM} \mathrm{K} \mathrm{K}^{+}$, (4) Millipore water with $0.2 \mathrm{mM} \mathrm{K}^{+}$and $5.62 \mu \mathrm{M}$ PHE, (5) Millipore water with $6 \mathrm{mM} \mathrm{K}^{+}$, and (6) Millipore water with $6 \mathrm{mM} \mathrm{K}^{+}$and $5.62 \mu \mathrm{M}$ PHE. After $4 \mathrm{~h}$ of incubation, $\mathrm{pH}$ values of incubation solution were measured with a $\mathrm{pH}$ meter. The experiment was performed as described in $\mathrm{K}^{+}$-dependent uptake of PHE.

\section{Extraction and analysis of PHE}

The PHE in wheat was extracted and detected using the method of Zhan et al. [14]. After harvest, wheat roots were immersed in methanol for $3 \mathrm{~min}$, and then rinsed with sufficient Millipore water to remove the PHE on root surface, followed by wiping with tissue paper $[46,47]$. Wheat roots and shoots were weighed and ground in a glass homogenizer. Homogenized tissue samples were extracted with acetone/hexane $(1: 1, \mathrm{v} / \mathrm{v})$ mixture by ultrasonication three times (30 min each time). The combined extracts were passed through an anhydrous $\mathrm{Na}_{2} \mathrm{SO}_{4}$ column with elution of the $1: 1$ mixture of acetone and hexane. The eluents were then evaporated to dryness at $35^{\circ} \mathrm{C}$ in a rotary evaporator and dissolved in $12 \mathrm{~mL}$ hexane. Subsequently, the $12-\mathrm{mL}$ solvent was cleaned in a 2 -g silica gel column and eluted with $25 \mathrm{~mL}$ hexane/dichloromethane $(1: 1, \mathrm{v} / \mathrm{v})$ solvents. The eluents were evaporated to dryness again and dissolved in $2 \mathrm{~mL}$ methanol. Prior to the analysis of PHE by HPLC, all final extracts were filtered with $0.22 \mu \mathrm{m}$ filter [8]. The average recovery of PHE acquired by spiking wheat samples with standards is $95.2 \%$ for the entire procedure. None of the data reported here has been corrected for recovery.

The HPLC system employed consists of an automatic injector (Waters 717), a binary high-pressure pump (Waters 1525), a UV detector (Waters 2487), and a fluorescence detector (Waters 2475). Separations were performed with a reverse phase column (Waters Symmetry $C_{18}$ column, $5 \mu \mathrm{m}, 4.6 \times 150 \mathrm{~mm})$. The temperature of the HPLC column was kept constant at $30^{\circ} \mathrm{C}$. The mobile phase was methanol/Millipore water $(80: 20, \mathrm{v} / \mathrm{v})$, with a flow rate of $1 \mathrm{~mL} \mathrm{m^{-1 }}$. The injection volume was $10 \mu \mathrm{L}$. PHE was quantified at 293.5/395 $\mathrm{nm}$ (excitation/emission wavelength) and $254 \mathrm{~nm}$ for fluorescence and UV detector, respectively. Relative standard deviation $(n=5)$ was less than $2.85 \%$ for the method. The method detection limit was 48.5 pg PHE. Analytical standards were measured at the beginning of each series of analyses. Internal standard calibration was performed during the HPLC analyses.

\section{Statistical analyses}

Statistical analyses were performed with SAS software version 9.1.3 (SAS Institute Inc., Cary, NC, USA). PAH contents in wheat tissues and $\mathrm{pH}$ values of nutrient solution were subjected to one-way analysis of variance (ANOVA) and compared using Duncan's test at $P<0.05$.

\section{Abbreviations}

ANOVA: Analysis of variance; $\mathrm{Ba}^{2+}$ : Barium ion; fr wt: Fresh weight

$\mathrm{H}^{+}$: Proton; HATS: High-affinity transport system; HPLC: High performance liquid chromatography; $\mathrm{K}^{+}$: Potassium ion; LATS: Low-affinity transport system; MES: 2-(N-morpholino)ethanesulfonic acid; PAHs: Polycyclic aromatic hydrocarbons; PHE: Phenanthrene; Pi: Inorganic P; SD: Standard deviation; TEA $^{+}$: Tetraethlyammonium ion. 


\section{Competing interests}

The authors declare that they have no competing interests.

\section{Authors' contributions}

$X Z$, TJ and GX designed research; $X Z$ and $X L$ performed research; $X Z, X L, T J$ and $G X$ analyzed data; and $X Z, T J$ and GX wrote the paper. All authors read and approved the final manuscript.

\section{Acknowledgments}

This work was supported jointly by the National Natural Science Foundation of China (31370521), the National High Technology Research and Development Program of China (2009AA063103), the Fundamental Research Funds for the Central Universities (KYZ201145) and the Open Fund of the State Key Laboratory of Soil and Sustainable Agriculture (Institute of Soil Science, Chinese Academy of Sciences, 0812201223). We are grateful to Dr. Xiaorong Fan for her expert technical assistance in measurement of membrane potential. Thanks are also given to the two anonymous reviewers for their valuable comments.

Received: 30 January 2013 Accepted: 23 October 2013

Published: 26 October 2013

\section{References}

1. Johnson AR, Wick LY, Harms H: Principles of microbial PAH-degradation in soil. Environ Pollut 2005, 133:71-84.

2. Zhang $Y$, Tao S, Shen H, Ma J: Inhalation exposure to ambient polycyclic aromatic hydrocarbons and lung cancer risk of Chinese population. Proc Natl Acad Sci U S A 2009, 106(50):21063-21067.

3. Parrish ZD, White JC, Isleyen M, Gent MPN, lannucci-Berger W, Eitzer BD, Kelsey JW, Mattina Ml: Accumulation of weathered polycyclic aromatic hydrocarbons (PAHs) by plant and earthworm species. Chemosphere 2006, 64:609-618.

4. Menzie CA, Potocki BB, Santodonato J: Exposure to carcinogenic PAHs in the environment. Environ Sci Technol 1992, 26(7):1278-1284.

5. Phillips DH: Polycyclic aromatic hydrocarbons in the diet. Mutat Res 1999 443:139-147.

6. Kulhánek A, Trapp S, Sismilich M, Janků J, Zimová M: Crop-specific human exposure assessment for polycyclic aromatic hydrocarbons in Czech soils. Sci Total Environ 2005, 339:71-80.

7. Zhou Q, Sun T: Effects of environmental pollution on terrestrial ecosystem. In Environmental chemistry for the $21^{\text {st }}$ century. Edited by Ye C, Wang C, Jin L. Beijing: Science Press; 2004:219-227.

8. Kipopoulou AM, Manoli E, Samara C: Bioconcentration of polycyclic aromatic hydrocarbons in vegetables grown in an industrial area. Environ Pollut 1999, 106:369-380.

9. Samsøe-Petersen $L$, Larsen EH, Larsen PB, Bruun P: Uptake of trace elements and $\mathrm{PAHs}$ by fruit and vegetables from contaminated soils. Environ Sci Technol 2002, 36:3057-3063.

10. Gao Y, Zhu L: Plant uptake, accumulation and translocation of phenanthrene and pyrene in soils. Chemosphere 2004, 55:1169-1178.

11. Wild E, Dent J, Thomas GO, Jones KC: Direct observation of organic contaminant uptake, storage, and metabolism within plant roots. Environ Sci Technol 2005, 39:3695-3702.

12. Tao $Y$, Zhang $S$, Zhu Y, Christie P: Uptake and acropetal translocation of polycyclic aromatic hydrocarbons by wheat (Triticum aestivum L.) grown in field-contaminated soil. Environ Sci Technol 2009, 43:3556-3560.

13. Kang F, Chen D, Gao Y, Zhang Y: Distribution of polycyclic aromatic hydrocarbons in subcellular root tissues of ryegrass (Lolium multiflorum L.). BMC Plant Biol 2010, 10:210.

14. Zhan X, Ma H, Zhou L, Liang J, Jiang T, Xu G: Accumulation of phenanthrene by roots of intact wheat (Triticum aestivum L.) seedlings: passive or active uptake? BMC Plant Biol 2010, 10:52.

15. Zhan X, Zhang X, Yin X, Ma H, Liang J, Zhou L, Jiang T, Xu G: H ${ }^{+} /$phenanthrene symporter and aquaglyceroporin are implicated in phenanthrene uptake by wheat (Triticum aestivum L.) roots. J Environ Qual 2012, 41:188-196.

16. Kronzucker HJ, Szczerba MW, Britto DT: Cytosolic potassium homeostasis revisited: ${ }^{42} \mathrm{~K}$-tracer analysis in Hordeum vulgare L. reveals set-point variations in $\left[\mathrm{K}^{+}\right]$. Planta 2003, 217:540-546.

17. Maathuis FJM, Sanders D: Mechanism of high-affinity potassium uptake in roots of Arabidopsis thaliana. Proc Natl Acad Sci USA 1994, 91:9272-9276.
18. Maathuis FJM, Sanders D: Mechanisms of potassium absorption by higher plant roots. Physiol Plant 1996, 96:158-168.

19. Pyo YJ, Gierth M, Schroeder Jl, Cho MH: High-affinity $\mathrm{K}^{+}$transport in Arabidopsis: athak5 and akt1 are vital for seedling establishment and postgermination growth under low-potassium conditions. Plant Physiol 2010, 153:863-875.

20. Véry $A A$, Sentenac $H$ : Molecular mechanisms and regulation of $\mathrm{K}^{+}$ transport in higher plants. Annu Rev Plant Biol 2003, 54:575-603.

21. Kochian LV, Shaff JE, Lucas WJ: High affinity $\mathrm{K}^{+}$uptake in maize roots: $\mathrm{A}$ lack of coupling with $\mathrm{H}^{+}$efflux. Plant Physiol 1989, 91(3):1202-1211.

22. Britto DT, Kronzucker $\mathrm{HJ}$ : Cellular mechanisms of potassium transport in plants. Physiol Plant 2008, 133:637-650.

23. Hutchings VM: Sucrose and proton cotransport in Ricinus cotyledons. II. $\mathrm{H}^{+}$efflux and associated $\mathrm{K}^{+}$uptake. Planta 1978, 138:237-241.

24. Du Z, Zhou J, Wang H, Chen X, Wang Q: Soil pH changes from fertilizer site as affected by application of monocalcium phosphate and potassium chloride. Commun Soil Sci Plant Anal 2010, 41:1779-1788.

25. Hirsch RE, Lewis BD, Spalding EP, Sussman MR: A role for the AKT1 potassium channel in plant nutrition. Science 1998, 280:918-921.

26. Fischer $E$, Lüttge U: Membrane potential changes related to active transport of glycine in Lemna gibba G1. Plant Physiol 1980, 65:1004-1008

27. Enríquez-Arredondo C, Sánchez-Nieto S, Rendón-Huerta E, GonzálezHalphen D, Gavilanes-Ruíz M, Díaz-Pontones D: The plasma membrane $\mathrm{H}^{+}$-ATPase of maize embryos localizes in regions that are critical during the onset of germination. Plant Sci 2005, 169:11-19.

28. Morth JP, Pedersen BP, Buch-Pedersen MJ, Andersen JP, Vilsen B, Palmgren $M G$, Nissen P: A structural overview of the plasma membrane $\mathrm{Na}^{+}$, $\mathrm{K}^{+}$-ATPase and $\mathrm{H}^{+}$-ATPase ion pumps. Nat Rev Mol Cell Biol 2011 12(1):60-70.

29. Briskin DP, Cawienowski MC: Role of the plasma membrane $\mathrm{H}^{+}$-ATPase in $\mathrm{K}^{+}$transport. Plant Physiol 1996, 111:1199-1207.

30. Sacchi GA, Espen L, Nocito F, Cocucci M: $\mathrm{Cs}^{+}$uptake in subapical maize root segments: Mechanism and effects on $\mathrm{H}^{+}$release, transmembrane electric potential and cell pH. Plant Cell Physiol 1997, 38(3):282-289.

31. Huang $W, Y u H$, Weber JWJ: Hysteresis in the sorption and desorption of hydrophobic organic contaminants by soil and sediments: 1 . A comparative analysis of experimental protocols. J Contam Hydrol 1998 31:129-148.

32. Xiao B, Yu Z, Huang W, Song J, Peng P: Black carbon and kerogen in soils and sediments. 2. Their roles in equilibrium sorption of less-polar organic pollutants. Environ Sci Technol 2004, 38:5842-5852.

33. Cerniglia CE: Biodegradation of polycyclic aromatic hydrocarbons. Biodegradation 1992, 3:351-368.

34. Chapin FS, Moilanen L, Kielland K: Preferential use of organic nitrogen for growth by a non-mycorrhizal article sedge. Nature 1993, 361:150-153.

35. Balkos KD, Britto D, Kronzucker HJ: Optimization of ammonium acquisition and metabolism by potassium in rice (Oryza sativa L. Cv. IR-72). Plant Cell Environ 2010, 33:23-34

36. Kronzucker HJ, Britto DT: Sodium transport in plants: a critical review. New Phytol 2011, 189:54-81.

37. Schulze LM, Britto DT, Li M, Kronzucker HJ: A pharmacological analysis of high-affinity sodium transport in barley (Hordeum vulgare L.): $a^{24} \mathrm{Na}^{+} /{ }^{42} \mathrm{~K}^{+}$ study. J Exp Bot 2012, 63(7):2479-2489.

38. Nocito FF, Sacchi GA, Maurizio C: Membrane depolarization induces $\mathrm{K}^{+}$ efflux from subapical maize root segments. New Phytol 2002, 154:45-51.

39. Wang S, Zhang J, Flowers TJ: Low-affinity $\mathrm{Na}^{+}$uptake in the halophyte Suaeda maritime. Plant Physiol 2007, 145:559-571.

40. ten Hoopen F, Cuin TA, Pedas P, Hegelund JN, Shabala S, Schjoerring JK, Jahn TP: Competition between uptake of ammonium and potassium in barley and Arabidopsis roots: molecular mechanisms and physiological consequences. J Exp Bot 2010, 61(9):2303-2315.

41. Schachtman DP, Schroeder JL, Lucas WJ, Anderson JA, Gaber RF: Expression of an inward-rectifying potassium channel by the Arabidopsis KAT1 cDNA. Science 1992, 258:1654-1658.

42. Basso B, Ullrich-Eberius Cl: Membrane potential and proton cotransport of alamne and phosphate as affected by permeant weak acids in Lemna gibba. Plant Physiol 1987, 85:674-678.

43. McClure PR, Kochian LV, Spanswick RM, Shaff JE: Evidence for cotransport of nitrate and protons in maize roots. I. Effect of nitrate on the membrane potential. Plant Physiol 1990, 93:281-289. 
44. Yan F, Zhu Y, Müller C, Zörb C, Schubert S: Adaptation of $\mathrm{H}^{+}$-pumping and plasma membrane $\mathrm{H}^{+}$-ATPase activity in proteoid roots of white lupin under phosphate deficiency. Plant Physiol 2002, 129:50-63.

45. Liang Y, Zhang W, Chen Q, Liu Y, Ding R: Effect of exogenous silicon (Si) on $\mathrm{H}^{+}$-ATPase activity, phospholipids and fluidity of plasma membrane in leaves of salt-stressed barley (Hordeum vulgare L.). Environ Exp Bot 2006, 57:212-219.

46. Schwab AP, Al-Assi AA, Banks MK: Adsorption of naphthalene onto plant roots. J Environ Qual 1998, 27:220-224.

47. Jiao X, Xu F, Dawson R, Chen S, Tao S: Adsorption and absorption of polycyclic aromatic hydrocarbons to rice roots. Environ Pollut 2007, 148:230-235.

doi:10.1186/1471-2229-13-168

Cite this article as: Zhan et al:: Interaction of phenanthrene and potassium uptake by wheat roots: a mechanistic model. BMC Plant Biology 2013 13:168.

\section{Submit your next manuscript to BioMed Central and take full advantage of:}

- Convenient online submission

- Thorough peer review

- No space constraints or color figure charges

- Immediate publication on acceptance

- Inclusion in PubMed, CAS, Scopus and Google Scholar

- Research which is freely available for redistribution 